\title{
THE PRINCIPLE OF THE USEFULNESS OF A WAQF OBJECT IN THE PERSPECTIVE OF NAZHIR PROFESSIONALISM BASED ON LAW NUMBER 41 YEAR 2004 ABOUT WAQF IN SUB-DISTRICT CIAWI AND SUB-DISTRICT MEGAMENDUNG BOGOR
}

\section{ASAS KEMANFAATAN OBJEK WAKAF DALAM PERSPEKTIF PROFESIONALITAS NAZHIR BERDASARKAN UNDANG-UNDANG NOMOR 41 TAHUN 2004 TENTANG WAKAF DI WILAYAH KECAMATAN CIAWI DAN KECAMATAN MEGAMENDUNG KABUPATEN BOGOR}

\author{
Siti Sulastri*, Ani Yumarni**, Sudiman Sihotang,*** \\ sitisulastri111@gmail.com
}

(Diterima pada: 01-07-2018 dan dipublikasikan pada: 30-09-2018)

\begin{abstract}
Realizing the expediency principle of waqf property, one of the efforts that be able to conducted is selecting and appointing nazhir that is conform the criteria and standards of professional nazhir competence. The purpose of study is to determine the criteria and professional nazhir competence in order to realize the expediency principle to assets of waqf in Ciawi and Megamendung district as well as to know the legal effect on waqf asset if nazhir not professional in managing and developing it. The approach method used in this research is sociological juridical (empirical), the law as a symptom of society, as a social institution or behavior that is pattern. Technical data collection used is through observation method, and interview method (interview). Based on results of research conducted by the author that the criteria and standards of professional nazhir competence is proficient, reasonable, law waqf understanding both Syariah and law, behaved as has been exemplified by the prophet Muhammad SAW namely sidiq, amanah, fathanah, tabligh, and possess skills and creativity not only in the field of syariah but law field, management and business. The legal consequences of the unmanaged asset of waqf in accordance to the legislation are the objects of waqf being displaced so that the management and its development can be taken over by the Badan Wakaf Indonesia, accordance to applicable laws and regulations.
\end{abstract}

Keywords: Nazhir Professionalism, Expediency Principle, Waqf

\begin{abstract}
ABSTRAK
Dalam mewujudkan asas kemanfaatan terhadap harta benda wakaf, salah satu upaya yang dapat dilakukan adalah dengan memilih dan menunjuk nazhir yang sesuai dengan kriteria dan standar kompetensi nazhir profesional. Tujuan dari penelitian ini adalah untuk mengetahui kriteria dan standar kompetensi nazhir profesional dalam rangka mewujudkan asas kemanfaatan terhadap aset wakaf di wilayah Kec. Ciawi dan Kec. Megamendung serta untuk mengetahui akibat hukum terhadap aset wakaf jika nazhir belum profesional dalam mengelola dan mengembangkannya. Metode pendekatan yang digunkan dalam penelitian ini adalah yuridis sosiologis (empiris), yaitu hukum sebagai gejala masyarakat, sebagai institusi sosial atau perilaku yang mempola. teknis pengumpulan data yang digunakan adalah melalui metode observasi, dan metode Interview (wawancara). Berdasarkan hasil penelitian yang dilakukan penulis bahwa kriteria dan standar kompetensi nazhir profesional adalah cakap, berakal sehat, faham hukum wakaf baik secara syariat maupun Undang-undang, memiliki
\end{abstract}

\footnotetext{
*Fakultas Hukum-Universitas Djuanda Bogor, Jl.Tol Ciawi No 1, Kotak Pos 35 Bogor 16770

** Fakultas Hukum-Universitas Djuanda Bogor, Jl.Tol Ciawi No 1, Kotak Pos 35 Bogor 16770

*** Fakultas Hukum-Universitas Djuanda Bogor, Jl.Tol Ciawi No 1, Kotak Pos 35 Bogor 16770
} 
attitude seperti yang telah di contohkan oleh Nabi Muhammad SAW yaitu sidik, amanah, fathanah dan tabligh. Serta memiliki skill dan kreatifitas bukan hanya dalam bidang syari'ah melainkan dalam bidang hukum, manajemen dan bisnis. Adapun akibat hukum terhadap aset wakaf yang belum dikelola sesuai dengan aturan perundang-undangan ialah objek wakaf menjadi terlantar sehingga pengelolaan dan pengembangaannya dapat diambil alih oleh Badan Wakaf Indonesia, sesuai dengan peraturan perundang-undangan yang berlaku.

Kata Kunci : Profesionalitas Nazhir, Asas Kemanfaatan, Wakaf

\section{A. Pendahuluan}

Negara Indonesia dikenal sebagai Negara Hukum. Hal ini ditegaskan dalam UUD 1945 Pasal 1 ayat (3) yaitu Negara Indonesia adalah negara hukum. Negara hukum merupakan dasar negara dan pandangan hidup setiap warga negara Indonesia, serta Pancasila merupakan sumber dari semua tertib hukum yang berlaku di negara Republik Indonesia. Negara hukum, menempatkan hukum pada posisi yang tertinggi, kekuasaan harus taat pada hukum bukan hukum pada kekuasaan, apabila hukum harus tunduk pada kekuasaan, dengan demikian kekuasaan bisa membatalkan hukum, maka hukum dijadikan sebagai alat untuk membenarkan keinginan kekuasaan. Sementara hukum haruslah bertujuan melindungi kepentingan rakyat. ${ }^{1}$ Selain itu tujuan dari diadakannya hukum di negara Indonesia, ialah sebagai sarana kontrol sosial (social control), yaitu proses baik direncanakan ataupun tidak direncanakan, bersifat mendidik dan mengajak atau/dan memaksa masyarakat agar mematuhi sistem kaidah serta nilai yang berlaku. ${ }^{2}$

\footnotetext{
1 Ilman Khairi, Martin Roestamy, Pengembangan Model Asas Droit De Preference Terhadap Kepemilikan Tempat Usaha Pada Pasar Tanah Abang Jakarta, Jurnal Hukum De'rechtsstaat, Volume 3 No. 2, September 2017, HIm. 120

2 Teguh Prasetyo dan Abdul Halim Barkatullah, Filsafat, Teori \& Ilmu Hukum, PT Raja Grafindo Persada,Jakarta,2014. HIm.364
}

Oleh karena itu, negara Indonesia sebagai salah satu negara yang merupakan negara hukum, harus memiliki aturan-aturan yang dapat diterapkan dalam kehidupan rakyatnya.

Sebagai pembinaan hukum nasional dibentuklah aturan berupa UU Nomor 41 Tahun 2004 tentang Wakaf. Dalam Pasal 1 ayat (1) dijelaskan pengertian Wakaf. Dalam Pasal 215 ayat (1) Buku ke III Bab I Kompilasi Hukum Islam dijelaskan wakaf merupakan perbuatan hukum seseorang/badan hukum yang memisahkan harta yang dimiliknya dan melembagakannya untuk selama-lamanya guna kepentingan ibadah atau keperluan umum ....".

Perwakafan atau wakaf, merupakan salah satu amalan yang dianjurkan dalam agama Islam kepada seseorang, sebagai sarana untuk menyalurkan sebagian rezeki/harta yang Allah SWT. Berikan kepadanya. Adanya wakaf juga merupakan salah satu lembaga yang berfungsi sebagai lembaga sosial Islam yang erat kaitannya dengan sosial ekonomi masyarakat. $^{3}$

Sebagai salah satu lembaga yang memiliki fungsi sosial, maka wakaf ini diharapkan dapat membantu menciptakan kesejahteraan umum untuk seluruh masyarakat Indonesia.

Amanat untuk memajukan kesejahteraan umum sebagaimana tersebut dalam pembukaan Undang

\footnotetext{
${ }^{3}$ http://repository.uinjkt.ac.id/dspace/bitstream/123 456789/3948/1/SAMSUDIN-FSH.pdf diakses pada tgl 25 Juli 2017
} 
Undang Dasar 1945 dijabarkan dalam Pasal 28H ayat (1) Undang Undang Dasar 1945 yang menyatakan bahwa "setiap orang berhak hidup sejahtera lahir dan batin, bertempat tinggal dan mendapatkan lingkungan hidup yang baik dan sehat". Dengan demikian memajukan kesejahteraan umum merupakan tugas dan juga tanggung jawab konstsitusi negara, bukan hanya sekedar hak setiap warga negara yang tertulis dalam undang-undang. ${ }^{4}$

Selain itu wakaf memiliki nilai ibadah dan nilai sosial, dikatakan memiliki nilai ibadah ialah karena seseorang yang telah menafkahkan hartanya di jalan Allah sebagai amal shaleh semata mata ia lakukan itu untuk mencari keridhoan Allah SWT. hal ini sebagaimana telah dijelaskan dalam AlQur'an yang artinya: "Kamu sekali-kali tidak sampai kepada kebajikan (yang sempurna), sebelum kamu menafkahkan sebagian harta yang kamu cintai. Dan apa saja yang kamu nafkahkan, maka sesungguhnya Allah mengetahuinya." 5 (QS. Ali Imran, 92). SAW

Sebagaimana sabda Rasulullah

Dari Abu Hurairah r.a, sesungguhnya Rasulullah SAW bersabda: "apabila anak Adam (Manusia) meninggal dunia, maka putuslah amalnya, kecuali tiga perkara, yaitu: shadaqah jariyah, ilmu yang bermanfaat, dan anak shaleh yang mendo'akan orang tuanya." (HR Muslim). ${ }^{6}$

Berdasarkan kutipan ayat diatas, maka terlihat secara jelas bahwa manusia diperintahkan untuk memberikan sebagian hartanya, untuk digunakan dijalan Allah. Kemudian hadits di atas

\footnotetext{
${ }^{4}$ Sudiman Sihotang, Optimalisasi Hukum Perumahan Untuk Percepatan Pengadaan Rumah Untuk Masyarakat Yang Berpenghasilan Rendah (MBR), Jurnal Hukum De'rechtsstaat, Volume 2 No. 1, Maret 2016, HIm.82

${ }^{5}$ Al-Qur'an dan Terjemahannya, Syamil Qur'an, Syigma, Jakarta, 2007. HIm. 62

${ }^{6}$ Sri Nurhayati, Wasilah, Akuntansi Syariah di Indonesia, Salemba Empat, Jakarta, 2013, HIm. 336
}

menjelaskan bahwa, apabila salah satu dari tiga hal diantara yang disebutkan Nabi Muhammad SAW itu terpenuhi, maka sudah cukup bagi seorang muslim untuk dipandang amalnya masih berlanjut sekalipun ia telah meninggal. ${ }^{7}$ Dengan demikian wakaf dalam bentuk benda seperti tanah dan uang merupakan suatu perwujudan yang nyata dari suatu perbuatan kebaikan yang dilakukan oleh seorang muslim.

Mengingat besarnya manfaat dan fungsi wakaf, Nabi Muhammad SAW beserta para sahabatnya, dengan ikhlas telah mewakafkan masjid, tanah, sumur, kebun, ataupun kuda milik mereka pribadi untuk digunakan oleh masyarakat. Jejak (sunah) nabi dan para sahabatnya itu kemudian diikuti oleh umat Islam sampai sekarang. ${ }^{8}$

Sejak zaman Rasulullah SAW wakaf telah disyariatkan, sebagian ulama berpendapat bahwa wakaf pertama dalam Islam adalah masjid Quba, dan kebanyakan ulama menyepakati wakaf yang dilakukan oleh Umar sebagai bagian dari wakaf pertama dalam Islam, sehingga yang menjadi pijakan dalam masalah ini (wakaf) adalah bahwasanya Amirul Mukminin Umar bin al-Khathab memiliki tanah di Khaibar ${ }^{9}$, tanah tersebut adalah harta paling berharga yang beliau miliki.

Keberadaan wakaf di negara Republik Indonesia, mempunyai kedudukan dan peranan yang penting. Pada hakikatnya harta benda wakaf memiliki potensi yang sangat besar dalam membantu mengatasi masalah sosial

\footnotetext{
7 Muhammad Tahir Azhary, et al, Beberapa Aspek Hukum Tata Negara,Hukum Pidana,dan Hukum Islam, Kencana Prenada Media Group, Jakarta, 2012. HIm.312

${ }^{8}$ Mardani, Hukum Islam Zakat, Infak, Sedekah, dan Wakaf, PT Citra Aditya Bakti, Bandung, 2016. HIm 165

${ }^{9}$ Khaibar adalah salah satu perang yang terjadi pada tahun ke-7 H. antara umat Islam yang di pimpin oleh Nabi Muhammad SAW dengan umat Yahudi yang hidup di oasis Khaibar sekitar 150 km dari Madinah, Arab Saudi.
} 
ekonomi masyarakat, serta meningkatkan kesejahteraan masyarakat di Indonesia.

Hal ini dapat dibuktikan dengan banyaknya jumlah tanah wakaf yang telah diberikan oleh masyarakat serta luasnya wilayah di Indonesia dengan jumlah penduduk yang mayoritas menganut agama Islam menjadi faktor pendukung utamanya.

Adapun hal yang menonjol dalam wakaf adalah peranannya dalam membiayai berbagai kegiatan agama (Islam), pendidikan dan kesehatan. Dalam kacamata sosial ekonomi, wakaf tentu harus dikelola dengan produktif sehingga memberikan kontribusi guna meningkatkan kesejahteraan masyarakat serta membantu pemerintah ${ }^{10}$

Seperti halnya wakaf dalam bentuk tanah, kedudukan tanahnya tetap sebagai tanah wakaf, akan tetapi tanah itu dikembangkan secara optimal untuk kegiatan ekonomi (bisnis) sehingga dapat menghasilkan keuntungan yang lebih besar. Hasil dari pemanfaatan tanah wakaf ini dapat digunakan untuk membantu mengatasi masalah perekonomian masyarakat Indonesia.

Akan tetapi pada pelaksanannya, tantangan dalam pengelolaan harta benda wakaf belum bisa diatasi dengan baik, sehingga meskipun harta benda wakaf yang seharusnya memiliki potensi yang besar untuk membantu mengatasi permasalahan ekonomi masyarakat, namun kurangnya pemanfaatan terhadap harta benda wakaf khususnya tanah, mengakibatkan penggunaan harta benda wakaf ini tidak sesuai dengan apa yang diharapkan.

Dengan demikian, seorang nazhir sebagai orang yang diberi kewenangan untuk mengurus dan mengelola harta benda wakaf harus mampu mengkaji, menganalisis, dan menerapkan strategi dalam rangka mengembangkan aset wakaf secara berkesinambungan, sehingga wakaf dapat bermanfaat sebagaimana mestinya.
Dalam usaha optimalisasi wakaf serta pengembangannya dipperlukan usaha untuk berpedoman pada berbagai aspek hukum wakaf sebagaimana dipraktikan pada masa sejarah Islam. ${ }^{11}$

Oleh karena itu, lahirnya UU No. 41 Tahun 2004 mengenai Wakaf serta UU No. 5 Tahun 1960 mengenai Peraturan Dasar Pokok-Pokok Agraria adalah upaya yang dilakukan oleh pemerintah dalam menjembatani proses pelaksanaan wakaf di Indonesia.

Sebelum lahirnya UU ini, perwakafan telah dilaksanakan oleh masyarakat tanpa didasari oleh aturan yang jelas, sehingga banyak harta benda wakaf khususnya tanah tidak terdaftar bahkan banyak juga yang tidak memiliki sertifikat karena pada saat itu pelaksanaan wakaf hanya dilakukan oleh wakif (orang yang mewakafkan), nazhir (orang yang menerima harta wakaf dan memiliki kewenangan untuk mengelolanya) serta saksi.

Pelaksanaan wakaf ini tidak dilakukan dihadapan Pejabat Pembuat Akta Ikrar Wakaf (PPAIW) sebagai pejabat yang memiliki kewenangan untuk mengeluarkan Akta Ikrar Wakaf (AIW), nazhirnya tidak terdaftar dan tanah sebagai objek wakafnya pun tidak didaftarkan sehingga tidak memiliki sertifikat dan berpotensi memunculkan beberapa permasalahan, diantaranya :

1. Nazhir tidak tidak memiliki kemampuan dalam mengembangkan aset wakaf dan nazhir tidak bisa mendapatkan pembinaan. Pasal 13 UU No. 41 Tahun 2004 menyatakan bahwa nazhir mendapatkan pembinaan dari Menteri dan Badan Wakaf Indonesia. Dan Pasal 14 menjelaskan bahwa dalam rangka pembinaan, nazhir harus terdaftar pada Menteri dan Badan Wakaf Indonesia. Jika seorang nazhir tidak memiliki kemampuan dan tidak bisa mendapatkan pembinaan, maka nazhir tidak bisa mengelola dan 
mengawasi serta mengembangkan harta benda wakaf dengan baik.

2. Pasal 3 ayat (1) PP Nomor 42 Tahun 2006 tentang Pelaksanaan Undangundang Nomor 41 Tahun 2004 tentang Wakaf menyatakan bahwa " Harta benda wakaf harus didaftarkan atas nama nazhir untuk kepentingan pihak yang dimaksud dalam Akta Ikrar Wakaf sesuai dengan peruntukannya".

Dengan demikian, Tanah wakaf yang tidak terdaftar dan tidak memiliki sertifikat hak milik dimana sertifikat ini merupakan akta otentik, maka hal itu seringkali menjadi penyebab sengketa antara ahli waris wakif dengan masyarakat setempat hingga mengakibatkan hilangnya hak atas tanah wakaf tersebut.

Berdasarkan latar belakang yang telah penulis uraikan di atas, maka identifikasi masalah dalam penelitian ini adalah:

1. Apa kriteria dan standar kompetensi nazhir profesional dalam rangka mewujudkan asas kemanfaatan terhadap aset wakaf di wilayah Kec. Ciawi dan Kec. Megamendung Kab. Bogor?

2. Bagaimana akibat hukum terhadap objek wakaf apabila nazhir belum profesional dalam mengurus dan mengelola harta benda wakaf?

Dalam kajian ini, peneliti menggunakan metode penelitian yang bersifat analisa deskriptif kualitatif dengan jenis penelitian yuridis sosiologis (empiris). Metode penelitian ini digunakan untuk membuat uraian secara jelas mengenai fakta-fakta yang terjadi di masyarakat dengan memadukan hasil studi lapangan dengan studi kepustakaan sehingga akan menghasilkan data-data yang akurat.
B. Pelaksanaan Pengawasan dan Pengelolaan Harta Benda Wakaf Serta Peran Fungsi Nazhir Wakaf di Wilayah Kec. Ciawi dan Kec. Megamendung Kab. Bogor.

Tujuan wakaf pada dasarnya adalah sebagai suatu sarana yang dapat digunakan untuk berbagai kemaslahatan umat yaitu dengan memenuhi kepentingan umum/sosial. Selain itu, harta benda wakaf juga dapat dimanfaatkan secara produktif dan ekonomis sehinga pemanfaatan harta benda wakaf ini dapat, menciptakan kesejahteraan bagi masyarakat.

Dengan lahirnya beberapa UU ini maka semakin memperkuat peraturan pelaksanaan perwakafan di Indonesia, dimana perwakafan diatur dan dilindungi oleh syari'at agama Islam serta dalam perkembangannya perwakafan juga di atur dan dilindungi oleh hukum nasional.

Mengenai legalitas tanah wakaf tersebut dimulai dari pengesahan ikrar wakaf. ${ }^{12}$

Dalam hal ini Pejabat Pembuat Akta Ikrar Wakaf (PPAIW) merupakan lembaga khusus yang dibentuk untuk membantu masyarakat dalam melaksanakan pengelolaan dan pengawasan terhadap tanah wakaf. Pejabat Pembuat Akta Ikrar Wakaf (PPAIW) sangat berperan aktif terhadap proses pembuatan Akta Ikrar Wakaf.

PPAIW harta benda wakaf tidak bergerak berupa tanah adalah Kepala KUA dan/atau pejabat yang menyelenggarakan urusan wakaf. Kantor Urusan Agama (KUA) merupakan suatu lembaga bagian dari sistem kementrian Agama yang bertugas melaksanakan tugas kementerian Agama di wilayah kecamatan. PPAIW ini memiliki kewenangan yang sah menurut hukum

\footnotetext{
${ }^{12}$ Rizal Anshor, (Skripsi) : Fungsi dan Kewenangan Pejabat Pembuat Akta Ikrar Wakaf (PPAIW) Terhadap Pendaftaran Tanah Wakaf, Fakultas Syariah dan Hukum, UIN Syarif Hidayatullah Jakarta, 2011. Hlm 69
} 
untuk membuat Akta Ikrar Wakaf (AIW), yang mana akta yang dibuat ini ialah untuk menguatkan kehendak seorang wakif (yang mewakafkan) harta bendanya untuk diwakafkan.

Meskipun di beberapa kecamatan di kabupaten Bogor banyak tanah wakaf yang pengelolaanya sudah cukup baik, akan tetapi praktik wakaf yang terjadi dalam kehidupan masyarakat di Kecamatan Ciawi dan Kec. Megamendung belum sepenuhnya berjalan secara efektif dan efisien. Ada beberapa kendala yang dihadapi oleh PPAIW Kec. Ciawi dan PPAIW Kec. Megamendung, beberapa kendala tersebut adalah sebagai berikut: PPAIW belum bisa melaksanakan pengawasan secara maksimal, kurangnya kesadaran masyarakat, kurangnya pemahaman masyarakat terhadap perundangundangan tentang wakaf, serta masih banyak masyarakat yang belum memahami bagaimana proses pelaksanaan wakaf yang sesuai dengan UU. Sehingga dalam praktiknya wakif sebagai orang yang mewakafkan harta bendanya untuk kepentingan umum menjadi kurang selektif dalam menunjuk nazhir sebagai pengelola tanah wakaf. ${ }^{13}$

PPAIW Kec. Ciawi dan PPAIW

Kec. Megamendung dalam menjawab permasalahan ini, tengah melakukan beberapa upaya untuk mengatasinya, diantara upaya yang dilakukan adalah dengan melaksanakan sosialisasi kepada masyarakat tentang pentingnya mengurus administrasi pelaksanaan wakaf yang sesuai dengan aturan perundangundangan serta mempermudah masyarakat dalam mengurus administrasi pendaftaran tanah wakaf hingga ke Badan Pertanahan Nasional (BPN). ${ }^{14}$

\footnotetext{
${ }^{13}$ Wawancara dengan Bapak Tapi Puad Kepala KUA/PPAIW Kec. Megamendung Kab. Bogor, Selasa, 3 April 2018. Pukul 11.25 WIB

${ }^{14}$ Wawancara dengan Bapak Roby Samsi Kepala KUA/PPAIW Kec. Ciawi Kabupaten Bogor, selasa, 27 Maret 2018. Pukul 11.00 WIB dan Wawancara dengan Bapak Abdul Azid Staf Pengurus Adm.
}

Undang-undang wakaf menentukan upaya bagi pembinaan para nazhir yang profesional, maka dibentuk lembaga baru yang independen, yaitu Badan Wakaf Indonesia (BWI). Di antara tugas dan wewenang badan ini, bersama-sama dengan Menteri Agama, adalah melakukan pembinaan terhadap nazhir untuk mengelola, mengembangkan, dan memanfaatkan harta benda wakaf, sehingga para nazhir menjadi profesional di dalam melakukan tugasnya. ${ }^{15}$

BWI hadir sebagai usaha membina nazhir hal ini bertujuan agar wakaf dikelola lebih baik dan lebih produktif. BWI berkedudukan di ibukota Negara dan dapat membentuk perwakilan di provinsi, kabupaten, dan/atau kota sesuai dengan kebutuhan. ${ }^{16}$

Pelaksanaan wakaf yang terjadi di kehidupan masyarakat Indonesia khususnya masyarakat di kecamatan Ciawi dan kecamatan Megamendung Kabupaten Bogor, belum sepenuhnya berjalan secara efektif dan efisien. Hal ini dapat dibuktikan dengan banyaknya harta benda (aset) wakaf yang tidak digunakan sebagaimana mestinya, belum dikelola dengan baik sehingga aset wakaf tidak bisa dikembangkan secara produktif. Selain itu banyak aset wakaf yang terlantar dan tidak jelas kepemilikannya dan hal inilah yang menjadi penyebab terjadinya sengketa antara ahli waris wakif dengan masyarakat.

Berdasarkan pernyataan diatas, maka nazhir sebagai seseorang yang diberi kepercayaan memegang tanggung jawab untuk mengelola, mengembangkan serta memanfaatkan aset wakaf oleh wakif dan masyarakat, diharapkan mampu melaksakan tugas dan fungsinya dengan baik dan sesuai dengan aturan

\footnotetext{
Zawaibsos KUA Kec. Megamendung. Selasa 27

Maret 2018 Pukul 14.45 WIB

15 Tata Fathurrohman, Nazhir Menurut hukum Islam dan Undang-Undang Nomor 41 Tahun 2004 tentang Wakaf,Disampaikan pada acara workshop perberdayaan wakaf yang diselenggarakan oleh BWI Jabar dan Kemenag Jabar, 10-12 Juni 2015. Hlm 2

${ }^{16}$ Siska Lis Sulistiani, Op Cit Hlm. 134
} 
perundang-undangan yang telah ditetapkan.

Tugas dan Kewajiban nazhir menurut hukum fikih dalam garis besarnya adalah melakukan segala hal yang berkaitan dengan perlindungan terhadap barang wakaf, penjagaan terhadap kemaslahatannya dan pengembangannya. ${ }^{17}$

Adapun tugas dan fungsi nazhir wakaf di Kabupaten Bogor adalah sebagai berikut ${ }^{18}$

(a) Wajib mengelola serta mengembangkan harta benda wakaf sebagaimana fungsi, tujuan, dan peruntukannya.

(b) pengembangan dan Pengelolaan harta benda wakaf oleh nazhir harus sesuai dengan prinsip syariah.

(c) Dalam pengelolaan dan pengembangan harta benda wakaf, nazhir dilarang mengubah peruntukan harta benda wakaf kecuali atas dasar izin tertulis dari Menteri/rek. BWI.

(d) Nazhir wajib mengelola pengadministrasian benda wakaf dan melaporkan dari hasil kegiatannya kepada Badan Wakaf indonesia.

(e) Nazhir mengawasi/melindungi wakaf agar jangan hilang.

Praktik wakaf yang dilaksanakan di Kecamatan Ciawi dan Kecamatan Megamendung mayoritas masih dilaksanakan dan dikelola oleh nazhir perorangan, dan jenis wakaf yang digunakan adalah wakaf ahli (wakaf dzurri) yaitu wakaf yang diperuntukkan untuk kepentingan dilingkungan kerabat keluarga, wakaf jenis ini memungkinkan rentan terhadap berbagai permasalahan karena dalam pelaksanaan wakaf jenis ini, nazhir yang dipilih oleh wakif ialah anggota keluarganya sendiri dan biasanya wakif menunjuk nazhir tanpa

\footnotetext{
17 Tholhah Hasan, Pemberdayaan Nazhir, Jurnal Wakaf dan Ekonomi Islam Volume IV, Nomor 04, Januari 2011, Hlm. 6

${ }^{18}$ Data diperoleh dari Kantor Perwakilan Badan Wakaf Indonesia Kabupaten Bogor
}

memperhatikan pemahaman dan kemampuan nazhir dalam mengelola harta benda wakaf.

Sebagaimana telah dijelaskan dalam bab sebelumnya, seorang nazhir menempati pos yang sangat sentral, dalam pola pengelolaan harta. Ditinjau dari segi tugas nazhir, dimana dia berkewajiban untuk menjaga, mengembangkan, dan melestarikan manfaat dari harta yang diwakafkan bagi orang-orang yang berhak menerimanya. ${ }^{19}$

Profesionalitas seorang nazhir dalam mengembangkan aset wakaf sangat berpotensi terhadap keberhasilan pengelolaan aset wakaf. Para nazhir di Kabupaten Bogor, khususnya di Kecamatan Ciawi dan Kecamatan Megamendung belum maksimal dalam mengembangkan dan memanfaatkan aset wakaf secara produktif.

Sebagaimana tercantum dalam data yang diperoleh dari Kantor Kementrian Agama Kabupaten Bogor. Data ini menunjukkan bahwa aset wakaf berupa tanah di Kabupaten Bogor secara keseluruhan berjumlah 5686 lokasi. 5075 lokasi $(89,25 \%)$ sudah memiliki sertifikat, 61 lokasi $(1,07 \%)$ status tanah wakafnya masih diproses di BPN, 550 lokasi $(9,67 \%)$ baru memiliki AIW, $248(4,86 \%)$ lokasi wakaf berupa kuburan, 2139 lokasi (37,61\%) masjid, 1478 lokasi $(25,99 \%)$ mushalla, 368 lokasi $(6,47 \%)$ majelis taklim, 146 lokasi $(2,56 \%)$ sekolah, 367 lokasi $(6,45 \%), 3$ lokasi $(0,05 \%)$ sosial, 24 lokasi $(0,42)$ lembaga pemerintahan, 8 lokasi $(0,14 \%)$ pertanian, 101 lokasi $(1,77 \%)$ untuk yang lainnya. ${ }^{20}$ Data ini menunjukkan sebagian besar para nazhir di kabupaten Bogor belum mampu mengembangkan aset wakaf secara produktif.

Jumlah aset wakaf yang ada di kecamatan Ciawi seluruhnya berjumlah 220 lokasi. 117 lokasi $(53,18 \%)$ sudah bersertifikat dan 103 lokasi $(46,81 \%)$ belum bersertifikat. 51 lokasi $(43,58 \%)$

\footnotetext{
${ }^{19}$ Ibid Hlm. 52

${ }^{20}$ Data diperoleh dari Kantor Kementrian Agama Kabupaten Bogor
} 
berupa masjid, 15 lokasi $(12,82 \%)$ berupa madrasah, 6 lokasi $(5,12 \%)$ berupa sarana keagamaan, 34 lokasi $(29,05 \%)$ berupa sarana pendidikan Agama Islam, 5 lokasi $(4,27 \%)$ berupa Majelis Taklim, 2 lokasi $(1,70 \%)$ berupa makam umum, dan 4 lokasi $(3,41 \%)$ berupa kepentingan umum.

Sedangkan jumlah aset wakaf yang ada di Kecamatan Megamendung seluruhnya berjumlah 89 lokasi. 84 lokasi $(94,38 \%)$ sudah bersertifikat, 4 lokasi $(4,49 \%)$ belum bersertifikat tetapi sudah memiliki Akta Ikrar Wakaf (AIW) dan 1 lokasi $(1,12 \%)$. 2 lokasi $(2,24 \%)$ berupa kuburan, 57 lokasi $(64,04 \%)$ berupa masjid, 5 lokasi $(5,61 \%)$ berupa mushalla, 5 lokasi $(5,61 \%)$ berupa majelis taklim, 7 lokasi $(7,86 \%)$ pesantren, 1 lokasi $(1,12 \%)$ lembaga pemerintahan, dan 1 lokasi $(1,12 \%)$ yang lainnya.

Berdasarkan data di atas, pengelolaan dan pengawasan yang dilakukan oleh nazhir, serta pengawasan terhadap aset wakaf yang dilaksanakan oleh PPAIW Kec. Ciawi, Kec. Megamendung dan Perwakilan BWI Kab. Bogor belum dilaksanakan secara maksimal. Adapun kendala utama yang dihadapi oleh PPAIW dan Perwakilan BWI Kab. Bogor adalah kurangnya sumber daya manusia serta tidak adanya anggaran dana yang bisa digunakan untuk melaksanakan pembinaan secara langsung terhadap nazhir, sehingga nazhir tidak bisa mendapatkan pembinaan, aset wakaf belum bisa dikembangkan secara produktif, dan pemanfaatan aset wakaf belum maksimal dan masih bersifat pasif.

\section{Kriteria dan Standar Kompetensi Nazhir Profesional dalam Rangka Mewujudkan Asas Kemanfaatan Terhadap Aset Wakaf di Wilayah Kec. Ciawi dan Kec. Megamendung Kab. Bogor.}

Antusiasme masyarakat Kecamatan Ciawi dan Kecamatan Megamendung cukup besar terhadap pelaksanaan wakaf, akan tetapi penerapan aturan yang kurang tegas serta minimnya kepastian hukum mengakibatkan perwujudan asas kemanfaatan terhadap wakaf di kedua wilayah tersebut belum berjalan secara optimal. Sebagaimana telah disebutkan dalam bab sebelumnya, serta berdasarkan hasil pengamatan di lapangan bahwa di Kecamatan Ciawi dan Kecamatan Megamendung Kabupaten Bogor, UU tentang wakaf belum berjalan dengan optimal serta pengawasan terhadap pelaksanaan wakaf belum dilakukan secara maksimal.

Dalam hal ini, nazhir merupakan salah satu pihak yang memiliki peran penting dalam pengelolaan dan pengawasan harta benda wakaf, karena nazhir adalah orang yang diberi amanah untuk memelihara, menjaga, mengurus, mengembangkan harta benda wakaf sesuai dengan peruntukkannya serta mengawasi dan menjamin keberadaan harta benda wakaf agar tidak hilang siasia.

Kualitas seorang nazhir dalam mengelola harta benda wakaf sangat mempengaruhi keberhasilan terlaksana/tidaknya perwakafan. Sebagaimana telah disebutkan dalam bab sebelumnya, sebuah benda wakaf dikatakan berhasil mencapai kegunaannya, jika :

1. Memberi manfaat bagi masyarakat sekitar atau lingkup yang lebih besar, dan juga bagi wakif serta nazhirnya

2. Tidak terbengkalai dan selalu terpelihara dari waktu ke waktu

3. Tidak menimbulkan masalah apalagi sengketa

Pada dasarnya untuk mewujudkan keberhasilan dalam pengelolaan aset wakaf diperlukan profesionalisme nazhir yang andal dan mempunyai keahlian dalam me-manage benda wakaf itu secara baik dan benar. ${ }^{21}$ Nazhir profesional adalah nazhir yang bukan hanya memenuhi kriteria dan standar kompetensi yang telah ditetapkan oleh

\footnotetext{
${ }^{21}$ Abdul Manan, Op Cit Hlm. 269
} 
UU, akan tetapi nazhir profesional adalah nazhir yang jujur, amanah, visioner, mampu menjaga dan mengembangkan aset wakaf, mampu bertanggung jawab terhadap tugasnya dalam menyelenggarakan urusan-urusan harta benda wakaf dan dia mampu mewujudkan asas kemanfaatan terhadap aset wakaf dengan sebaik baiknya. ${ }^{22}$

Melihat kepada persyaratan sebagaimana tersebut diatas, maka perlu ditingkatkan kemampuan nazhir dalam sistem manajemen sumber daya manusia agar mempunyai pengetahuan, kemampuan dan keterampilan pada semua tingkatan dalam mengembangkan dan mengelola wakaf. Di samping itu, perlu dibentuk sikap serta perilaku nazhir wakaf sesuai pada posisi yang seharusnya, yaitu pemegang amanat umat yang mempercayakan harta bendanya untuk dikelola secara baik dan bertanggungjawab dihadapan Allah SWT. ${ }^{23}$

Salah satu bukti nyata keberhasilan nazhir dalam pengelolaan harta benda wakaf ini, adalah dengan terwujudnya asas kemanfaatan terhadap objek wakaf dan masyarakat dapat menerima serta merasakan manfaatnya secara langsung. Asas kemanfaatan merupakan salah satu asas umum hukum Islam yang meliputi semua bidang dan lapangan hukum Islam.

Asas kemanfaatan terhadap aset wakaf diwujudkan dengan adanya tim nazhir yang bekerja secara profesional dan memenuhi kriteria serta standar kompetensi yang telah ditentukan. Salah satu kriteria utama yang harus dimiliki oleh seorang nazhir adalah memiliki pemahaman yang agama yang baik sesuai dengan yang telah dicontohkan oleh Nabi Muhammad SAW. Yaitu sidik, amanah, fathanah, dan tabligh. Selain itu, standar kompetensi yang harus dimiliki oleh seorang nazhir profesional adalah memiliki kemampuan yang mumpuni

\footnotetext{
${ }^{22}$ Wawancara dengan Bapak Roby Samsi, PPAIW Kec. Ciawi dan Bapak Tapi Puad, PPAIW Kec. Megamendung

${ }^{23}$ Abdul Manan, Op Cit Hlm. 270
}

dalam mengelola dan mengembangkan aset wakaf sesuai dengan tugas dan tanggungjawab yang diamanahkan kepadanya. Pengelolaan harta benda wakaf yang dilakukan secara profesional memberi peluang penerapan prinsipprinsip manajemen modern. ${ }^{24}$

\section{Akibat Hukum Terhadap Objek Wakaf Apabila Nazhir belum Profesional dalam Mengurus dan Mengelola Harta Benda Wakaf}

Di Kecamatan Ciawi dan Kecamatan Megamendung, pelaksanaan wakaf belum sepenuhnya dilakukan sesuai dengan aturan yang terkandung dalam UU No. 41 Tahun 2004 tentang wakaf dan PP No. 42 Tahun 2006 tentang Pelaksanaan UU No. 41 Tahun 2004 tentang wakaf disertai dengan aturan aturan yang ada didalam Kompilasi Hukum Islam (KHI).

Dalam tiga peraturan perundangundangan ini telah diterangkan dengan jelas bahwa pelaksanaan wakaf harus dilaksanakan sesuai dengan peraturan hukum Islam dan hukum nasional, karena sebagai negara hukum maka pelaksanaan wakaf akan dianggap sah (diakui secara hukum) apabila dilaksanakan sesuai dengan aturan perundang-undangan yang berlaku.

Pelaksanaan wakaf yang sah yaitu wakaf dilaksanakan di hadapan PPAIW, dimana PPAIW akan mengeluarkan Akta Ikrar Wakaf (AIW). AIW yang dikeluarkan oleh Pejabat Pembuat Akta Ikrar Wakaf (PPAIW) Kantor Urusan Agama (KUA) kecamatan, serta sertifikat hak milik yang dikeluarkan oleh Badan Pertanahan tingkat Kabupaaten merupakan bukti nyata (akta otentik) yang menguatkan keberadaan tanah wakaf.

Tentang ikrar (sighat) wakaf ini merupakan rukun wakaf yang disepakati

\footnotetext{
${ }^{24}$ Abdurrahman Kasdi, Peran Nazhir dalam Pengembangan Wakaf, Jurnal Pengembangan Wakaf 2014. Hlm 214
} 
oleh Jumhur Fuqaha. Tanpa adanya ikrar wakaf, para Fuqaha menganggap wakaf belum sempurna dilaksanakan, ${ }^{25}$ karena pembuatan AIW ini diawali dengan pengucapan Ikrar wakaf di hadapan PPAIW kecamatan setempat.

Dari penjelasan diatas maka timbul pertanyaan apakah jika pelaksanaan wakaf tidak dilaksanakan di hadapan PPAIW maka objek wakaf/tanah wakaf dapat memiliki kekuatan hukum yang sah. Sebagaimana telah dijelaskan pada bab sebelumnya bahwa telah diatur dalam Pasal 3 ayat (1) PP No. 42 Tahun 2006 tentang Pelaksanaan UU No. 41 Tahun 2004 tentang wakaf "Harta benda wakaf harus didaftarkan atas nama nazhir untuk kepentingan pihak yang dimaksud dalam AIW sesuai dengan peruntukannya". Artinya wakaf dianggap sah secara hukum nasional minimal apabila memiliki AIW.

Sebagaimana penjelasan diatas, peran pemerintah khususnya pemda kabupaten Bogor dan Perwakilan Badan Wakaf Indonesia Kabupaten Bogor, dalam rangka mewujudkan asas kemanfaatan terhadap pengelolaan dan kelestarian tanah wakaf itu sangatlah diperlukan.

Selain itu diperlukan juga sumber daya manusia yang lebih banyak dan memiliki kemampuan yang mumpuni dalam mengelola, melindungi dan mengawasi jalannya pelaksanaan wakaf. Hal ini dilakukan untuk mencapai kepastian hukum mengenai tanah wakaf serta menghindari hilangnya hak milik atas tanah wakaf yang tidak memiliki AIW dan sertifikat tanah wakaf yang rentan menimbulkan sengketa, karena pada dasarnya akibat hukum akan timbul jika objek wakaf tidak dikelola dengan baik sehingga terlantar atau di gunakan tidak sesuai dengan peruntukanya maka nazhirnya berhak untuk di berhentikan atau di gantikan dan objek wakafnya berhak untuk diambil alih pengelolaan

\footnotetext{
${ }^{25}$ Abdul Manan, Op Cit. Hlm. 241
}

dan pengembangannya oleh Badan Wakaf Indonesia.

\section{E. Kesimpulan}

1. Kriteria dan standar kompetensi nazhir profesional adalah sebagai berikut :

a. Cakap/dewasa;

b. Berakal sehat;

c. Tidak terhalang melakuakan perbuatan hukum;

d. Memiliki skill yang bukan hanya di bidang syariah, tetapi lebih baik lagi jika dilengkapi dengan skill dalam bidang hukum, manajemen dan bisnis;

e. Memiliki attitude yang baik sesuai dengan yang telah di contohkan oleh Nabi Muhammad SAW, yaitu sidik, amanah, fathanah, dan tabligh;

f. Memiliki keterampilan dan merupakan seorang pembelajar yang memiliki kesungguhan dan keseriusan dalam menjalankan pekerjaannya sebagai seorang nazhir;

g. Mampu menjaga, memelihara, mengelola dan mengembangkan aset wakaf serta tidak membiarkan aset wakaf terlantar sehingga tidak memberikan manfaat;

h. Memahami hukum perwakafan baik secara syari'at Islam maupun aturan perundang-undangan;

i. Memberikan hasil wakaf produktif kepada pihak-pihak yang berhak menerimanya;

j. Memiliki jiwa kepemimpinan (leadership) yang baik, sehingga dia mampu mengelola timnya untuk bersama-sama melakukan yang terbaik;

k. Memiliki etos kerja yang tinggi, dimana dia akan selalu berusaha bekerja keras, cerdas dan ikhlas.

Selain itu, seorang nazhir juga memiliki tugas untuk mempertanggungjawabkan aset wakaf yang telah diamanahkan kepadanya, 
$\begin{array}{llr}\text { pelaksanaan wakaf harus } & \text { dikelola } \\ \text { secara } & \text { transparan } & \text { dengan } \\ \text { mempertanggungjawabkan } & \text { baik }\end{array}$ kepada Allah SWT, kelembagaan, sosial masyarakat dan hukum. Salah satu bentuk keberhasilan nazhir dalam pengelolaan wakaf ini adalah dengan Terwujudnya asas kemanfaatan terhadap objek wakaf dan masyarakat dapat merasakan secara langsung manfaatnya.

2. Akibat hukum terhadap aset wakaf yang belum dikelola sesuai dengan syari'at Islam serta belum dikelola sesuai dengan aturan perundangundangan (terlantar, objek wakaf menjadi tidak jelas kepengurusannya) maka objek wakaf berhak untuk diambil alih pengelolaan serta pengembangannya oleh Badan Wakaf Indonesia. Sebagaimana telah dijelaskan dalam Pasal 8 Peraturan Badan Wakaf Indonesia Nomor 1 Tahun 2007 tentang Organisasi dan Tata Kerja Badan Wakaf Indonesia, bahwa salah satu tugas Badan Wakaf Indonesia adalah melakukan pengelolaan dan pengembangan harta benda wakaf berskala nasional dan internasional serta harta benda wakaf terlantar; Hal ini dilakukan untuk menjaga kelestarian objek wakaf serta untuk menciptakan perlindungan hukum terhadap objek wakaf, sehingga kekuatan hukum yang terkandung dalam objek wakaf tidak akan hilang sia-sia dan objek wakaf tetap bisa dikembangkan serta dimanfaatkan sebagaimana mestinya oleh masyarakat.

\section{Buku-Buku :}

\section{DAFTAR PUSTAKA}

Abdul Aziz Muhammad Azzam, Fiqh Muamaliyah, Amzah , Jakarta,, 2014

Abdul Djamali, Hukum Islam Berdasarkan Ketentuan Kurikulum Konsorsium Ilmu Hukum, Mandar Maju, Bandung, 2002

Abdul Manan, Aneka Masalah Hukum Perdata Islam Di Indonesia, Kencana Prenada Media Group, Jakarta, 2006

Achmad Ali, Menguak Teori Hukum (Legal Theory) dan Teori Peradilan (Judicialprudence), Kencana Pranada Media Group, Jakarta , 2009

Al-Qur'an dan Terjemahannya, Syamil Qur'an, Syigma, Jakarta, 2007

Ari Wahyudi Hertanto, Bunga Rampai Ilmu Hukum, Rizkita, Jakarta, 2010

Mardani,Hukum Islam Zakat, Infak, Sedekah, dan Wakaf, PT Citra Aditya Bakti,Bandung, 2016.

Martin Roestamy (et al), Metode, Penelitian, Laporan, dan Penulisan Karya Ilmiah Hukum Pada Fakultas Hukum, Unida Press, Bogor, 2014

Muhammad Tahir Azhary, et al, Beberapa Aspek Hukum Tata Negara,Hukum Pidana,dan Hukum Islam, Kencana Prenada Media Group, Jakarta, 2012

Paradigma Baru Wakaf Di Indonesia, Kementrian Agama Republik Indonesia Direktorat Jenderal Bimbingan Masyarakat Islam Direktorat Pemberdayaan Wakaf Tahun 2013, Jakarta, 2006

R.Abdoel Djamali, Pengantar Hukum Indonesia, PT Raja Grafindo Persada, Bandung, 2005

Rachmat Trijono, Dasar-Dasar Ilmu Pengetahuan Perundang-Undangan, Papas Sinar Sinanti, 2014.

Salim HS, dan Erlies Septiana Nurbana,Penerapan Teori Hukum Pada Penelitian Tesis dan Disertasi, PT Raja Grafindo Persada, Jakarta, 2013.

Sarja, Negara Hukum Teori dan Praktek, Thafamedia, Yogyakarta, 2012

Siska Lis Sulistiani, Pembaruan Hukum Wakaf di Indonesia, Refika Aditama, Bandung, 2017 
Sri Nurhayati, Wasilah, Akuntansi Syariah di Indonesia, Salemba Empat, Jakarta, 2013

Standar Pelayanan Wakaf Bagi Pejabat Pembuat Akta Ikrar Wakaf, Direktorat Pemberdayaan Wakaf 2013

Standar Profesionalisme Nazhir, Kementrian Agama Republik Indonesia Direktorat Jenderal Bimbingan Masyarakat Islam Direktorat Pemberdayaan Wakaf Tahun 2015, Jakarta, 2015

Teguh Prasetyo dan Abdul Halim Barkatullah, Filsafat, Teori \& Ilmu Hukum, PT Raja Grafindo Persada,Jakarta,2014

Uswatun Hasanah, Aspek Hukum Wakaf Uang,Badan Pembinaan Hukum Nasional Kementrian Hukum dan Hak Asasi Manusia RI, Jakarta, 2011

Yulies Tiena Masriani,Pengantar Hukum Indonesia,Sinar Grafika, Jakarta, 2004

Zainudin Ali, Hukum Islam, Sinar Grafika, Jakarta, 2013

\section{Peraturan Perundang-Undangan :}

Undang-Undang Dasar 1945;

Kompilasi Hukum Islam

Undang-Undang Nomor 5 Tahun 1960 tentang Peraturan Dasar Pokok pokok Agraria (UUPA)

Undang-Undang Nomor 41 Tahun 2004 tentang Wakaf

Peraturan Pemerintah Nomor 42 Tahun 2006 tentang Pelaksanaaan Undang-Undang Nomor 41 Tahun 2004 tentang Wakaf

Peraturan Pemerintah Nomor 28 Tahun 1977 tentang Perwakafan Tanah Milik

\section{Karya Ilmiah / Jurnal :}

Abdurrahman Kasdi, Peran Nazhir dalam Pengembangan Wakaf, Jurnal Pengembangan Wakaf, 2014

Fatthurrahman Djamil, Standarisasi dan Profesionalisme Nazhir di Indonesia, Al-Awqaf Jurnal Wakaf dan ekonomi Islam Volume IV, nomor 04, Januari 2011

Ilman Khairi, Martin Roestamy, Pengembangan Model Asas Droit De Preference Terhadap Kepemilikan Tempat Usaha Pada Pasar Tanah Abang Jakarta, Jurnal Hukum De'rechtsstaat, Volume 3 No. 2, September 2017

Khazanah, Mocthar Kusumaatmadja, Padjajaran Jurnal Ilmu Hukum, Volume 1-No-3- Tahun 2014

Kurnisar, Pancasila Sebagai Sumber dari Segala Sumber Hukum di Indonesia, Universitas Sriwijaya Palembang

Mudtaba Feri Ferdiansyah, (Skripsi) : Pewarisan Tanah Wakaf Oleh Ahli Waris Wakif Dihubungkan dengan Hukum Islam dan Undang-undang Nomor 41 Tahun 2004, Fakultas Hukum, Unpad, 2010.

Rizal Anshor, (Skripsi) : Fungsi dan Kewenangan Pejabat Pembuat Akta Ikrar Wakaf (PPAIW) Terhadap Pendaftaran Tanah Wakaf, Fakultas Syariah dan Hukum, UIN Syarif Hidayatullah Jakarta, 2011

Ramlan, Tinjauan Filosofis Aspek Kepastian Hukum Antara Pemerintah dengan Pemerintah Daerah dalam Implementasi Undang-undang Penanaman Modal di Indonesia, Jurnal Ilmu Hukum volume 3 No. 1

Sudiman Sihotang, Optimalisasi Hukum Perumahan Untuk Percepatan Pengadaan Rumah Untuk Masyarakat Yang Berpenghasilan Rendah (MBR), Jurnal Hukum De'rechtsstaat, Volume 2 No. 1, Maret 2016

Sudri Heryana, Yeyen Heryaningrum,Beragam Istilah Dalam Program Sertifikasi Tanah Secara Massal, Sebuah Ide atau Rebutan Citra, Jurnal Hukum De'rechtsstaat, Volume 1 No. 1, Maret 2015 
Tata Fathurrohman, Nazhir Menurut hukum Islam dan Undang-Undang Nomor 41 Tahun 2004 tentang Wakaf,Disampaikan pada acara workshop perberdayaan wakaf yang diselenggarakan oleh BWI Jabar dan Kemenag Jabar , 10-12 Juni 2015

Tholhah Hasan, Pemberdayaan Nazhir, Jurnal Wakaf dan Ekonomi Islam Volume IV, Nomor 04, Januari 2011

Zainur Rosyid, (Skripsi: Persepsi Pimpinan Daerah Muhammadiyah Kabupaten Lumajang Terhadap Legalitas Wakaf Produktif Dalam Perspektif Hukum Islam dan Hukum Positif, Fakultas Syari'ah dan Hukum Islam,UIN Sunan Ampel, 2015

\section{Sumber Elektronik :}

http://repository.uinjkt.ac.id/dspace/bitstream/123456789/3948/1/SAMSUDIN-FSH.pdf http://siwak.kemenag.go.id/tabel_jumlah_tanah_wakaf.php http://www.suduthukum.com/2015/10/lahirnya-uu-no-41-tahun-2004-tentang.wakaf https://profgunarto.files.wordpress.com/2012/12/mph-1.pdf

http://www.lontar.ui.ac.id

http://nadzarsukses.blogspot.co.id/2015/01/perwakafan-di-indonesia 